\title{
A new species of Neoascarophis (Nematoda: Cystidicolidae) parasitic in Mullus argentinae (Perciformes: Mullidae) from the Atlantic coast of South America
}

\author{
Aldenice N. Pereira ${ }^{1}$, Juan T. Timi ${ }^{2}$, Fabiano M. Vieira ${ }^{1}$ and José L. Luque ${ }^{1}$ \\ ${ }^{1}$ Curso de Pós-Graduação em Ciências Veterinárias and Departamento de Parasitologia Animal, Universidade Federal Rural do Rio \\ de Janeiro, Caixa Postal 74.508, CEP 23851-970, Seropédica, RJ, Brasil; \\ ${ }^{2}$ Laboratorio de Parasitología, Instituto de Investigaciones Marinas y Costeras (IIMyC), Facultad de Ciencias Exactas y Naturales, \\ Universidad Nacional de Mar del Plata - Consejo Nacional de Investigaciones Científicas y Técnicas (CONICET), Funes 3350, \\ (7600) Mar del Plata, Argentina
}

\begin{abstract}
A new nematode species (Neoascarophis mariae n. sp.) is described based on specimens collected from the Argentine goatfish Mullus argentinae (Hubbs et Marini) from coastal waters off the state of Rio de Janeiro, Brazil. In the genus, the new species belongs to the group of species with females that have the vulva near the posterior end of the body. Only males of Neoascarophis longispicula Moravec et Klimpel, 2009 are known and can be distinguished from those of the new species by their larger body, developed and somewhat dorsoventrally expanded flat inner part of the pseudolabia, bifurcate deirids and larger spicules (the left one with a rounded tip) with a different length ratio. Other species with females that have the vulva near the equatorial region are $N$. yarihige Machida, 1976 and N. bathygadi Machida, 1976. Both males and females of N. yarihige are longer than those of the new species and have a shorter vestibule; males have shorter spicules with a different length ratio. Neoascarophis bathygadi is the only member of the genus that shares the presence of a cephalic vesicle with the new species, which, however, is shorter and arises at $40 \mu \mathrm{m}$ from the anterior end instead from the deirids, as in the new species. Both males and females of $N$. bathygadi are also longer than those of the new species and have a shorter vestibule; males have a larger left spicule, but shorter right spicule and a different length ratio. Ascarophis upeneichthys Johnston et Mawson, 1945, a parasite of a mullid host, is transferred to Neoascarophis Machida, 1976 and is distinguished from the new species by having a shorter vestibule in females and shorter spicules (left spicule with a pointed tip) with a different length ratio in males.
\end{abstract}

Keywords: Neoascarophis, Mullus argentinae, marine fish, nematode, South America

The Argentine goatfish, Mullus argentinae Hubbs et Marini (Perciformes, Mullidae), is a small benthic fish distributed from Rio de Janeiro, Brazil, to the coast of Buenos Aires province, Argentina (Cousseau and Perrotta 2004). Its parasite fauna is known at both extremes of its distribution: Rio de Janeiro (Luque et al. 2002) and Mar del Plata (Lanfranchi et al. 2009). However, there is no information on the intermediate regions. During an extensive study on the parasites of $M$. argentinae along the Atlantic coast of South America, a new cystidicolid species was found in the northern region of the sampling area, from where it was not reported in previous surveys (Luque et al. 2002). This species is described and illustrated herein.

\section{MATERIALS AND METHODS}

Four hundred and thirty specimens of $M$. argentinae caught by commercial trawlers along the Atlantic coast of South Amer- ica were examined for parasites (Table 1). The fish were dissected, their stomachs and intestines were removed and examined using a stereoscopic microscope. Nematodes of an unidentified species of Neoascarophis were collected, fixed in a $4 \%$ formaldehyde solution, transferred to $70 \%$ ethanol for storage, cleared in glycerine-ethanol and studied and measured using light microscopy. Drawings were made using a drawing tube. Micrographs were taken using an Olympus BX51 DIC (differential interference contrast) microscope.

For scanning electron microscopy (SEM), specimens were dehydrated in a series of ethanol washes, dried by evaporation with hexamethyldisilazane, coated with gold and scanned in a JEOL JSM 6460-LV SEM. All measurements are given in micrometres, unless otherwise indicated. Prevalence and mean intensity were calculated based on Bush et al. (1997). The holotype, allotype and paratypes are deposited in the Helminthological Collection of the Instituto Oswaldo Cruz (CHIOC), Rio de Janeiro, Brazil. Other paratypes are deposited in the helminthological collection of the Institute of Parasitology (IPCAS), České Budějovice, Czech Republic. 
Table 1. Samples of Mullus argentinae from along South American Atlantic coasts, including prevalence and mean abundance values for Neoascarophis mariae sp. n.

\begin{tabular}{|c|c|c|c|c|c|}
\hline Locality & Latitude-longitude & Date of capture & Hosts examined & Prevalence & Mean abundance (range) \\
\hline Rio de Janeiro, Brazil & $22^{\circ} 55^{\prime} \mathrm{S}, 43^{\circ} 12^{\prime} \mathrm{W}$ & Summer, 2009 & 50 & 60 & $3.5(1-29)$ \\
\hline Rio de Janeiro, Brazil & $22^{\circ} 55^{\prime} \mathrm{S}, 43^{\circ} 12^{\prime} \mathrm{W}$ & Spring, 2010 & 50 & 22 & $0.2(1-4)$ \\
\hline Rio de Janeiro, Brazil & $22^{\circ} 55^{\prime} \mathrm{S}, 43^{\circ} 12^{\prime} \mathrm{W}$ & Winter, 2010 & 50 & 22 & $0.5(1-5)$ \\
\hline Rio de Janeiro, Brazil & $22^{\circ} 55^{\prime} \mathrm{S}, 43^{\circ} 12^{\prime} \mathrm{W}$ & Autumn, 2011 & 50 & 52 & $3.8(1-27)$ \\
\hline Santa Catarina, Brazil & $27^{\circ} 10^{\prime} \mathrm{S}, 48^{\circ} 35^{\prime} \mathrm{W}$ & Winter, 2009 & 50 & 0 & 0 \\
\hline Santa Catarina, Brazil & $27^{\circ} 10^{\prime} \mathrm{S}, 48^{\circ} 35^{\prime} \mathrm{W}$ & Winter, 2010 & 50 & 0 & 0 \\
\hline Rio Grande do Sul, Brazil & $32^{\circ} 04^{\prime} \mathrm{S}, 52^{\circ} 09^{\prime} \mathrm{W}$ & Winter, 2010 & 50 & 0 & 0 \\
\hline Mar del Plata, Argentina & $38^{\circ} 27^{\prime} \mathrm{S}, 57^{\circ} 90^{\prime} \mathrm{W}$ & Winter, 2010 & 50 & 0 & 0 \\
\hline Mar del Plata, Argentina & $38^{\circ} 27^{\prime} \mathrm{S}, 57^{\circ} 90^{\prime} \mathrm{W}$ & Winter, 2011 & 30 & 0 & 0 \\
\hline
\end{tabular}

\section{RESULTS}

\section{Neoascarophis mariae sp. $\mathrm{n}$.}

General (Figs. 1A,B, 2A,B, 3A-C): Small-sized nematodes, females larger than males, cuticle thick with fine transverse striations. Cephalic end rounded in both sexes. Cuticle inflated in cephalic region forming a cephalic vesicle from anterior end to the level of deirids. Oral aperture oval, laterally depressed, surrounded by 4 large submedian labia (2 dorsolateral and 2 ventrolateral, each lateral pair partially fused), each bearing narrow sublabium on its inner side; sublabia interrupted by a notch near its medial end. Lateral pseudolabia as long as wide, each provided with oval apical protrusion, inner parts of pseudolabia covering mouth. Four submedian cephalic papillae and pair of lateral amphids present. Vestibule short with indistinct prostom visible in lateral view. Glandular part of oesophagus more than twice longer than muscular portion. Nerve-ring encircling muscular oesophagus near its posterior third. Deirids small, non-bifurcate, situated immediately anterior to nerve ring, excretory pore posterior to nerve ring.

Male (Figs. 1C-F, 2C, D, 3G) (10 specimens, ranges in parentheses): Body 5.0 (3.6-5.9) mm long, maximum width 116 (79-150). Vestibule, including very short prostom 56 (45-64) long. Length of muscular oesophagus 330 (300-380), width 28 (20-45); length of glandular oesophagus $1.153(0.963-1.587) \mathrm{mm}$; length ratio of muscular and glandular parts of oesophagus 1:3.5 (1:2.9-5.2); length of entire oesophagus and vestibule representing 31 (26-43) \% of total body length. Nerve-ring situated at 206 (183-227) from anterior extremity; deirids and excretory pore at 166 (128-198) and 272 (232-313), respectively, from anterior end. Posterior end of body spirally coiled, provided with narrow vesicular caudal ala. Pre-cloacal papillae: 4 pairs of subventral pedunculate papillae present, of which first and second plus third and fourth are almost at the same level, but first and third slightly lateral and anterior to second and fourth, respectively. Postcloacal papillae: 6 pairs present, including 5 pairs of pedunculate subventral papillae and 1 pair of minute ventral sessile papillae located at level of last subventral pair, first and second and fifth and sixth almost at the same level, but shifted laterally in relation to each other. In addition, 1 pair of very small ventral papilla-like phasmids present just posterior to caudal papillae. Serrate ventral cuticular ridges (area rugosa) anterior to cloaca. Left spicule 325 (272-390) long, with tapered distal tip and subterminal barb, providing a fish hook-like tip; its shaft representing about $30 \%$ of overall length of spicule. Right spicule, 156 (137-198) long, broad with inflate anterior end and rounded distal tip. Length ratio of spicules 1:2.1 (1:1.72.5). Tail conical, 132 (105-167) long, with rounded tip.

Female (Figs. 1G, H, 2E, F, 3D-F) (10 gravid specimens, ranges in parentheses): Body tapering slightly anteriorly but not posteriorly, widest in its posterior end, at level of anus. Length of body $7.1(5.1-9.9) \mathrm{mm}$; width at level of oesophagus-intestine junction 135 (99-163); maximum width 165 (112-222). Vestibule, including prostom, 46 (30-69) long. Length of muscular oesophagus 353 (315-494), width 34 (24-44); length of glandular oesophagus 1.528 (1.027-2.223) mm, width 77 (61-94); length ratio of muscular and glandular parts of oesophagus 1:4.3 (1:3.0-6.6); length of entire oesophagus and vestibule representing 27 (22-32) \% of total body length. Nerve-ring, excretory pore and deirids located at 194 (166-271), 268 (183-375) and 173 (143-232), respectively, from anterior extremity. Vulva equatorial, situated at $3.93(2.75-5.29) \mathrm{mm}$ from posterior end of body, at 59 (50-63) \% of body length; vulval lips not elevated. Tail 63 (49-79) long, with rounded tip, flanked by a pair of minute phasmids. Amphidelphic, uterus occupying major part of body, filled with numerous eggs. Mature eggs (containing larvae) oval, 36 (30-45) long and 18 (15-24) wide, thin-walled, with smooth surface and devoid of filaments.

Type host: Mullus argentinae Hubbs et Marini, 1933 (Perciformes, Mullidae).

Site of infection: Females and males were found free in the stomach and intestine.

Type locality: Coastal zone of Rio de Janeiro, Brazil $\left(22^{\circ} 55^{\prime} \mathrm{S}, 43^{\circ} 12^{\prime} \mathrm{W}\right)$.

Prevalence : $39 \%$ (78 fish infected of 200 examined in the type locality).

In te n s ity : 1-29 (mean 5.4). 

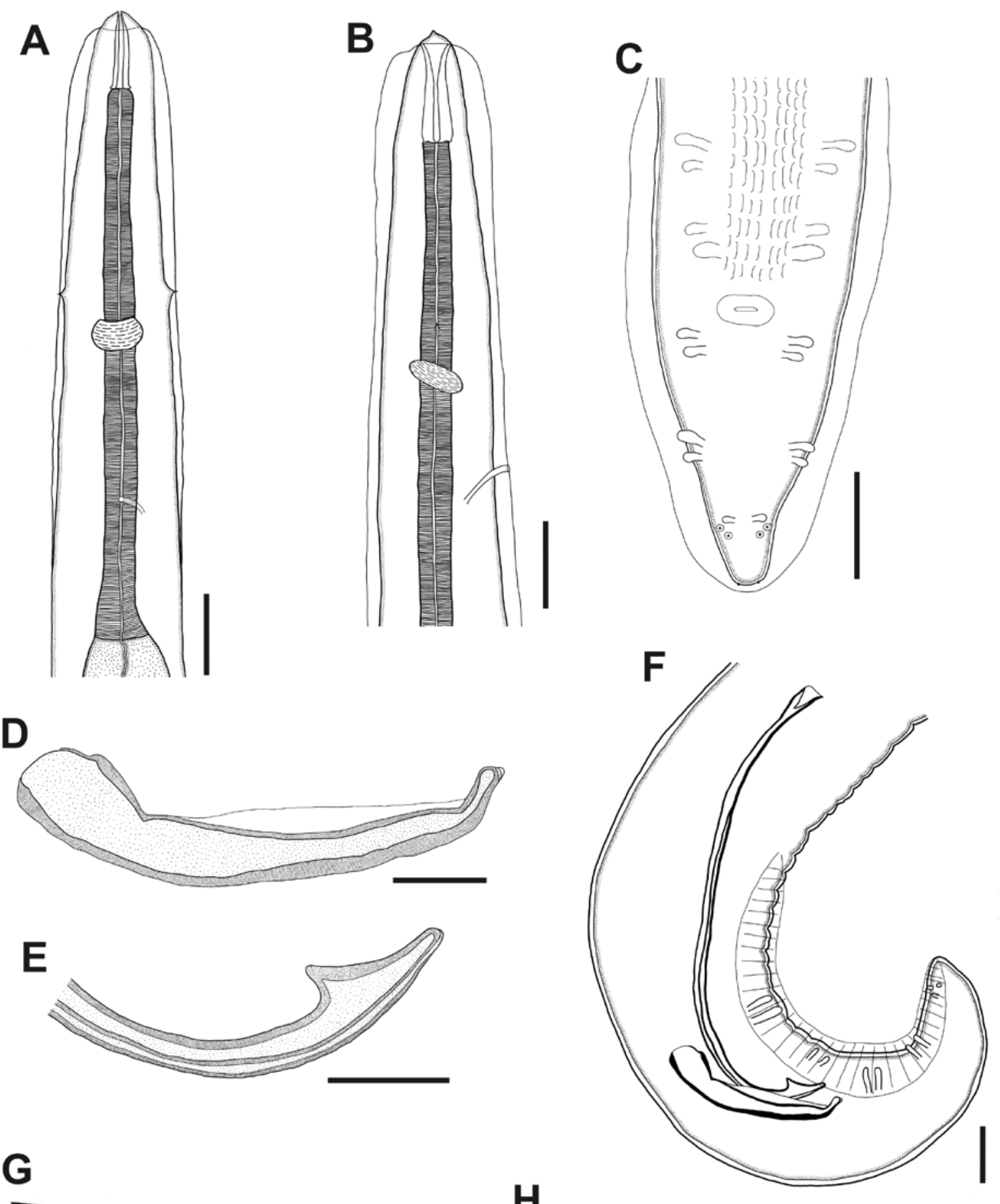

G
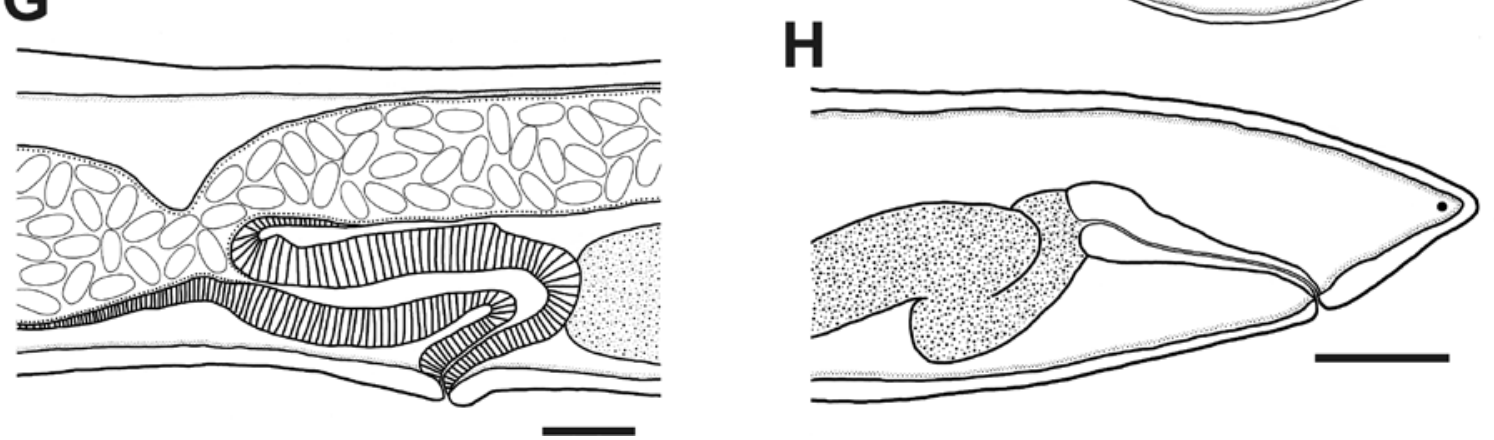

Fig. 1. Neoascarophis mariae sp. $n$. A - body anterior end, ventral view; $\mathbf{B}$ - body anterior end, lateral view; $\mathbf{C}$ - tail of male, ventral view; D - distal and of small (right) spicule; $\mathbf{E}$ - distal end of large (left) spicule; $\mathbf{F}$ - tail of male, lateral view; $\mathbf{G}$ - vulva, lateral

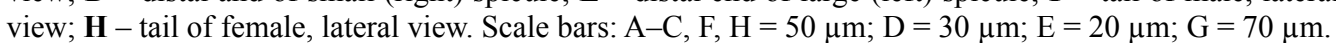



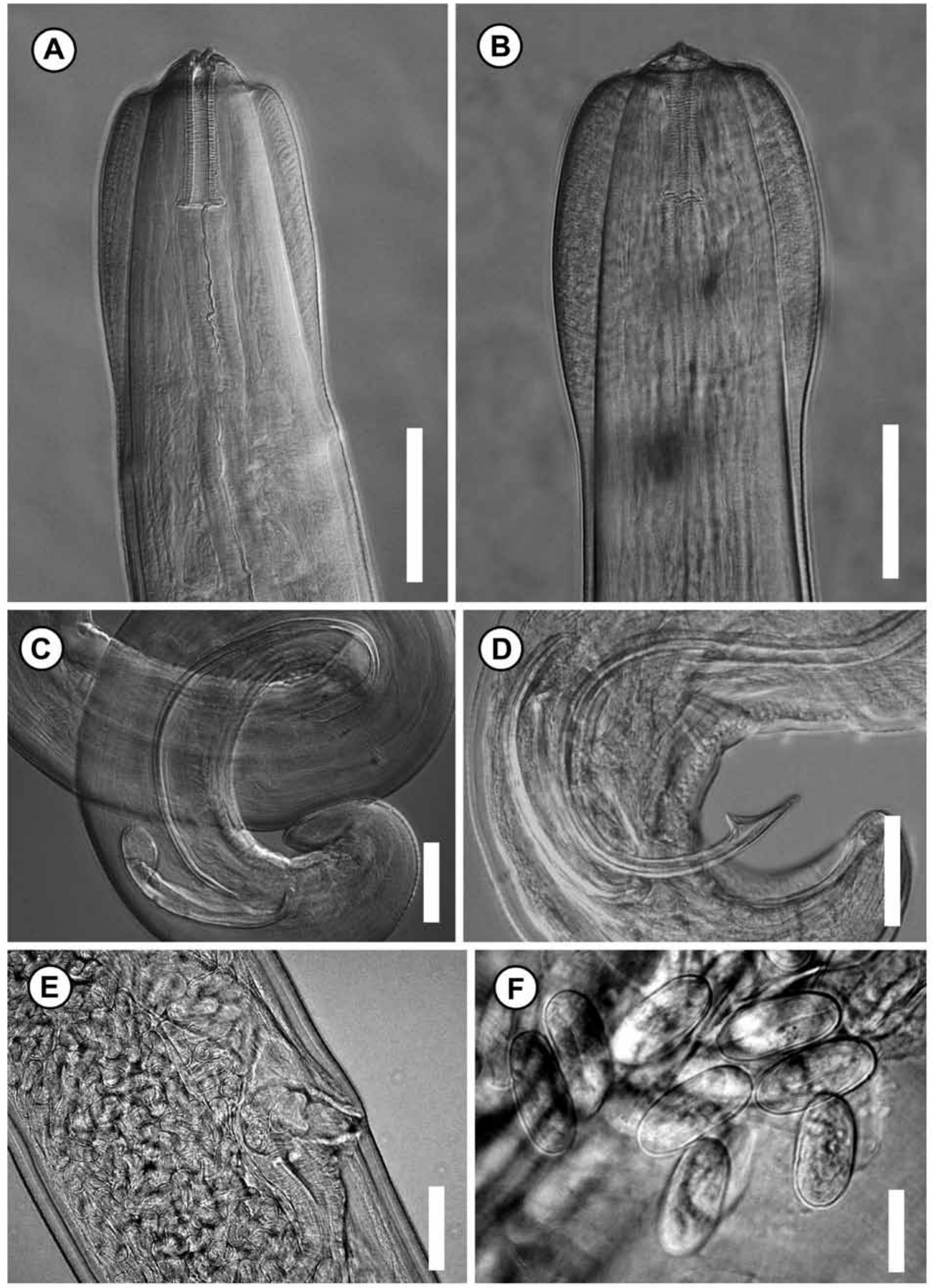

Fig. 2. Neoascarophis mariae sp. n., photomicrographs (differential interference contrast); $\mathbf{A}$, $\mathbf{B}$ - anterior end of body, ventral and lateral views; $\mathbf{C}$ - caudal region of male showing small and large spicules; $\mathbf{D}$ - distal end of large spicule; $\mathbf{E}$ - vulva; $\mathbf{F}$ - mature eggs. Scale bars: A, B, D, E = 50 $\mu \mathrm{m} ; \mathrm{C}=100 \mu \mathrm{m} ; \mathrm{F}=20 \mu \mathrm{m}$. 

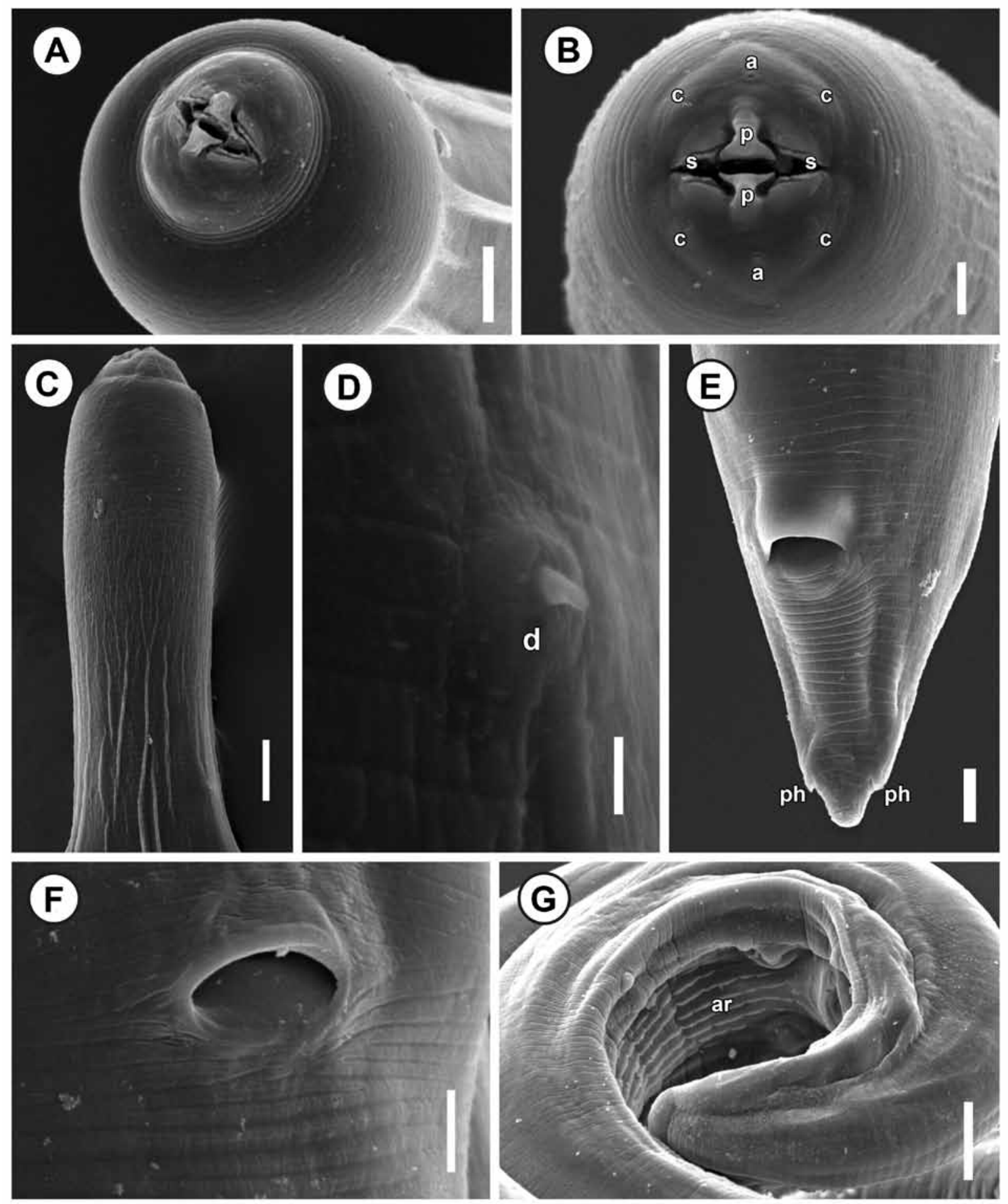

Fig. 3. Neoascarophis mariae sp. n., scanning electron micrographs. A-cephalic end, subapical view; $\mathbf{B}$ - cephalic end, apical view; $\mathbf{C}$ - cephalic end, lateral view; D - deirid; $\mathbf{E}$ - caudal end of female, ventral view; $\mathbf{F}$ - vulval region, ventral view; $\mathbf{G}$ - male tail showing ventral cuticular ridges (area rugosa) in precloacal region, ventral view. Abbreviations: a - amphid; ar - area rugosa; $\mathrm{c}-\mathrm{cephalic}$ papilla; $\mathrm{d}$ - deirid; $\mathrm{p}$ - pseudolabium; ph-phasmids; $\mathrm{s}$ - sublabium. Scale bars: $\mathrm{A}, \mathrm{E}-\mathrm{G}=10 \mu \mathrm{m} ; \mathrm{B}=5 \mu \mathrm{m} ; \mathrm{C}=20 \mu \mathrm{m} ; \mathrm{D}=3 \mu \mathrm{m}$. 
Mean abundance: 2.1 .

Deposition of types: Holotype, male (CHIOC No. 35802a), allotype, female (CHIOC No. 35803a) and paratypes, 15 females (CHIOC No. 35802b), 12 males (CHIOC No. 35803b), 5 females and 5 males (IPCAS No. N-982).

Ety mology: The new species is named in honour of the senior author's mother.

Comments: Nematodes of the family Cystidicolidae Skrjabin, 1946 are common parasites of mullids, with six species of the genus Ascarophis van Beneden, 1870 reported in mullets: A. upeneichthys Johnston et Mawson, 1945, a parasite of Upeneichthys lineatus (Bloch et Schneider); A. porosus (Cuvier, 1829), described in the Great Australian Bight (Johnston and Mawson 1945); A. mullusi Naidenova et Nikolaeva, 1968, described from M. surmuletus Linnaeus from the Aegean Sea and Mullus barbatus Linnaeus from the Adriatic Sea (Naidenova and Nikolaeva 1968); A. upenei Parukhin, 1978, a parasite of Upeneus vittatus (Forsskål) from the Indian Ocean; A. parupenei Moravec, Orecchia et Paggi, 1988 described from Parupeneus indicus (Shaw) from the Indian Ocean (Parukhin 1978, Moravec et al. 1988); A. valentina Ferrer, Aznar, Balbuena, Kostadinova, Raga et Moravec, 2005, described from M. surmulentus from the coast of Spain (Ferrer et al. 2005); and A. marina (Szidat 1961) described from M. argentinae from the coast of Mar del Plata, Argentina (Lanfranchi et al. 2009).

The classification of nematodes in Cystidicolidae is problematic (Moravec 2007), with several genera closely related to Ascarophis being erected or re-erected in recent decades on the basis of slight differences in cephalic structure (Moravec et al. 2006). Neoascarophis Machida, 1976 is distinguished from Ascarophis only by having a very short vestibule (Moravec et al. 2006). Although Machida (1976) pointed out differences in the mouth structure, this is practically identical in both genera (Ko 1986, Moravec et al. 2006). However, A. upeneichthys also has a short vestibule (Johnston and Mawson 1945). Due to this characteristic, Machida (1976) suggests that this species may belong to Neoascrophis. Nonetheless, while it has been compared with species of Neoascarophis in the erection of a new species of this genus (Moravec et al. 2006), A. upeneichthys has still been considered within Ascarophis in recent systematic studies (Ferrer et al. 2005, Brugni and Viozzi 2008).

A recent study on phylogenetic relationships of spirurine nematodes inferred from SSU rRNA gene sequences (Černotíková et al. 2011) showed that Neoascarophis is monophyletic, in contrast to the paraphyletic condition of Ascarophis, thereby confirming the validity of vestibule size as a diagnostic character of the genus. Thus, the specimens described by Johnston and Mawson (1945) as Ascarophis upeneichthys are transferred to Neoascarophis upeneichthys (Johnston et Mawson 1945) n. comb.

The species described herein is assigned to Neoascarophis based on the comparatively shorter vestibule than that found in members of Ascarophis. Neoascarophis currently comprises six species of parasites of macrourid fish (Moravec and Klimpel 2009): N. yarihige Machida, 1976 and N. bathygadi Machida, 1976 described from Coelorhynchus multispinulosus Katayama and Bathygadus garretti Gilbert et Hubbs, both from Suruga Bay off Japan; N. insulana (Solovjeva 1991) described from Coryphaenoides acrolepis (Bean) and Albatrossia pectoralis (Gilbert) off the northern Kurile Islands in the Pacific Ocean; N. macrouri Moravec, Klimpel et Kara, 2006 described from Macrourus berglax Lacépède from the eastern Greenland Sea, North Atlantic Ocean; N. longispicula Moravec et Klimpel, 2009 described from Coryphaenoides mediterraneus (Giglioli) from the Mid-Atlantic Ridge; and N. sphaerocaudata Rossin, Incorvaia et Timi, 2011 described from Macrourus carinatus (Günther) from Patagonian waters, Argentina (Machida 1976, Solovjeva 1991, Moravec et al. 2006, Moravec and Klimpel 2009, Rossin et al. 2012).

Among the species parasitizing macrourid fish, only the male is known for $N$. longispicula, which can be distinguished from that of the new species by its larger body ( $15.8 \mathrm{~mm}$ versus $5.0 \mathrm{~mm}$ in the new species), having a developed, somewhat dorsoventrally expanded flat inner part of the pseudolabia, bifurcate deirids and larger spicules (left spicule: 1149 vs. 325, with a rounded tip; right spicule: 351 vs. 157) with a different length ratio (1:5.3 vs. 1:2.1) (Moravec and Klimpel 2009). Among the remaining species, $N$. insulana, $N$. macrouri and $N$. sphaerocaudata are readily distinguished from the new species by having females with the vulva near the posterior end of body (Solovjeva 1991, Moravec et al. 2006), whereas the vulva is near the equatorial region in $N$. yarihige and N. bathygadi (Machida 1976). However, both males and females of $N$. yarihige are longer $(9-11.7 \mathrm{~mm}$ and $13.7-$ $14.6 \mathrm{~mm}$, respectively) than those of the new species and have shorter vestibules (33-40 and 38-44, respectively) and shorter spicules (left spicule: 240-300; right spicule: 90-120) with a different length ratio (1:2.5-2.7, calculated on ranges provided by Machida 1976). Neoascarophis bathygadi is the only member of the genus that shares the presence of a cephalic vesicle with the new species, which, however, is shorter and arises at 40 from the anterior end rather than from the deirids, as in the new species. Both males and females of $N$. bathygadi are also longer $(9.8-13.5 \mathrm{~mm}$ and $14.1-26.7 \mathrm{~mm}$, respectively) than those of the new species and have shorter vestibules (15-18 and 15-20, respectively) as well as a larger left spicule (420-500), but shorter right spicule (100-120), with a different length ratio (1:4.2, calculated on ranges provided by Machida 1976).

Neoascarophis upeneichthys is the only member of the genus described from a mullid host. Unfortunately, the original description by Johnston and Mawson (1945) is flawed in many aspects and lacks important morphometric features, such as the size of the vestibules and 
oesophagus in males. However, most of the few measurements provided by these authors and the body shape of females (widest at the level of the anus) are in agreement with those of the new species. Despite this, the vestibule is shorter (30) in females and the spicules are also shorter (left spicule: 260, with pointed tip; right spicule: 90), with a different length ratio (1:2.9, calculated from values provided by Johnston and Mawson 1945). On the basis of these differences, a new species of Cystidicolidae is proposed: Neoascarophis mariae n. sp.

The new species was only found in the Argentine goatfish in its northern limit of distribution. The parasite finding in all seasons indicates that its absence in southern regions is not a consequence of seasonal changes in infection. Two probable processes may explain this distribution pattern. First, there could be a specific environmental requirement for this parasite, such as a higher water temperature. Luque et al. (2004) suggest that the biodiversity of fish parasites around Rio de Janeiro may be con- strained by physical barriers (water currents, upwelling systems) that limit the arrival and, consequently, the dispersal of parasite taxa from other regions. Second, Mullus argentinae could be an accidental, although suitable, host for the new species. Indeed, the distribution of this fish overlaps with those of other mullids in the northern limit, such as Mulloidichthys martinicus (Cuvier), Pseudupeneus maculates (Bloch) and Upeneus parvus Poey, which do not reach lower latitudes (Froese and Pauly 2011). One or more of these species could be the definitive hosts for the new species.

Acknowledgements. Aldenice Pereira was supported by an MSc Fellowship from the Conselho Nacional de Desenvolvimento Científico e Tecnológico do Brazil (CNPq). Fabiano M. Vieira was supported by a Postdoctoral fellowship from CNPq. Financial support to Juan T. Timi was provided by grants from CONICET (PIP No. 112-200801-00024), ANPCYT (PICT No. 02199) and UNMdP (EXA 531/10). José L. Luque was supported by research fellowship from CNPq.

\section{REFERENCES}

BRUGNi N.L., Viozzi G.P. 2008: New cystidicolid species (Nematoda) from Galaxias platei (Osmeriformes: Galaxiidae) in Patagonian freshwater environments. J. Parasitol. 94: 841-846.

Bush A.O., Lafferty K.D., Lotz J.M., Shostak A.W. 1997: Parasitology meets ecology on its own terms: Margolis et al. revisited. J. Parasitol. 83: 575-583.

Černotíková E., Horák A., Moravec F. 2011: Phylogenetic relationships of some spirurine nematodes (Nematoda: Chromadorea: Rhabditida: Spirurina) parasitic in fishes inferred from SSU rRNA gene sequences. Folia Parasitol. 58: 135-148.

Cousseau M.B., Perrotta R.G. 2004: Peces marinos de Argentina. Biología, distribución, pesca. 2nd ed. Publicaciones especiales INIDEP, Mar del Plata, Argentina. 167 pp.

Ferrer E., Aznar F.J., Balbuena J.A., Kostadinova A., Raga J.A., Moravec F. 2005: A new cystidicolid nematode from Mullus surmuletus (Perciformes: Mullidae) from the western Mediterranean. J. Parasitol. 91: 335-344.

Froese R., Pauly D. (Eds.) 2011: FishBase. World Wide Web electronic publication. www.fishbase.org, version 08/2011.

Johnston T.H., Mawson P.M. 1945: Parasitic nematodes. B.A.N.Z. Antarctic Res. Exp. 1929-1931, 5: 73-159.

Ko R.C. 1986: A preliminary review of the genus Ascarophis van Beneden, 1871 (Nematoda: Cystidicolidae) of the gastrointestinal tract of fishes. Department of Zoology, University of Hong Kong, Hong Kong, China, 54 pp.

Lanfranchi A.L., Rossin M.A., Timi J.T. 2009: Parasite infracommunities of a specialised marine fish species in a compound community dominated by generalist parasites. J. Helminthol. 83: 373-378.

LuQue J.L., Mouillot D., Poulin R. 2004: Parasite biodiversity and its determinants in coastal marine teleost fishes of Brazil. Parasitology 128: 671-682.

Luque J.L., Porrozzi F., Alves D.R. 2002: Community ecology of the metazoan parasites of argentine goatfish, Mullus argentinae (Osteichthyes: Mullidae), from the coastal zone of the state of Rio de Janeiro, Brazil. Rev. Bras. Parasitol. Vet. 11: 33-38.
Machida M. 1976: Nematodes from the deep-sea fishes of Suruga Bay. II. Two new rhabdochonid nematodes from the macrouroid fishes. Bull. Nat. Sci. Mus., Ser. A (Zool.) 2: 1-6.

Moravec F. 2007: Some aspects of the taxonomy and biology of adult spirurine nematodes parasitic in fishes: a review. Folia Parasitol. 54: 239-257.

Moravec F., Klimpel S. 2009: Two new species of cystidicolid nematodes from the digestive tract of the deep-sea fish Coryphaenoides mediterraneus (Giglioli) (Macrouridae) from the Mid-Atlantic Ridge. Syst. Parasitol. 73: 37-47.

Moravec F., Klimpel S., Kara E. 2006: Neoascarophis macrouri $\mathrm{n}$. sp. (Nematoda: Cystidicolidae) from the stomach of Macrourus berglax (Macrouridae) in the eastern Greenland Sea. Syst. Parasitol. 63: 231-237.

Moravec F., Orecchia P., Paggi L. 1988: Three interesting nematodes from the fish Parupeneus indicus (Mullidae: Perciformes) of the Indian Ocean, including a new species, Ascarophis parupenei sp. n. (Habronematoidea). Folia Parasitol. 35: $47-57$.

Naidenova N.N., Nikolaeva V.M. 1968: On the nematode fauna of some benthic fishes of the Mediterranean basin. Biologiya Morya 14: 63-82. (In Russian.)

PARUKhin A.M. 1978: New species of nematodes from Indian Ocean fish. Materialy Nauchnoi Konferentsii Vsesoyuznogo Obshchestva Gel'mintologov (Biologicheskie osnovy bor'by s gel'mintozami cheloveka i zhivotnykh) 30: 125-129. (In Russian.)

Rossin M.A., Incorvaia I.S., Timi J.T. 2012. A new species of Neoascarophis (Nematoda: Cystidicolidae) parasitic in Macrourus carinatus (Macrouridae) from Argentinean waters. J. Parasitol. (In press.)

Solovjeva G. F. 1991: Metabronema insulanum sp. n. (Nematoda: Spirurina), a parasite of deep-sea fishes of the Pacific Ocean. Parazytologiya 25: 556-558. (In Russian.) 